\title{
The Literary Dimension of the Absurd and Black Humour in Catch-22
}

\author{
Anita Neziri \\ Lecturer at University of: \\ "Alexander Moisiu" Durres, Albania \\ anitaneziri@yahoo.com
}

\section{Doi:10.5901/mjss.2013.v4n9p376}

\begin{abstract}
In the center of this article, it is going to be a literary movement which was named absurdism, theatre of the absurd, articulates the meaninglessness of the total existence. Such meaninglessness deprives you from any importance human existence as in his overall personality also in his particular personality display, in every act, feeling and effort. As a literary trend, absurd belongs more to a literary formation order, which makes it different from many simultaneous activities and other literary movements in XX century, which found themselves in different forms of art- in paintings, music, cinamtography, sculpture, as there is on the one hand e.g symbolism, impressionism, expressionism, on the other hand, there is grotesque, montage, colazh etc. Secondly, this article will treat the ways how these tropes are elaborated by the postmodernist writers beginning from the ealier ones up to the latest representative authors such as J. Heller, K. Vonnegut, J. Hox, A. Jarrie etc. How do these writers reflect through their powerful word of art in their works? Thirdly, this article will deal with the efforts to be released from the "tyrany" of words and by the oppressivness of traditional literary contexts part of this, and "antiliterarism" as its distinguished trait. Finally,it is going to be concluded by the evaluation of significant critics and reviews, that will makes us understand better what happens especially seen from the Heller "Catch-22" point of view, and realizing major postmodern elements such as Black humor, grotesque, parody, irony, sarcasm etc.
\end{abstract}

Keywords: grotesque, parody, irony, meaninglessness, absurdity, existence

During my work at this paper I will reveal that Catch-22 belongs to the Literature of the Absurd, that Heller writes in the tradition of the absurd and that he uses absurdist techniques to describe his novel's absurd and disjointed world. The novel's absurd vision differs radically from other literature of the absurd because instead of admitting the universe as absurd, Heller protests against the absurdity he depicts. To support what i write about I will examine definitions and features of the Theatre of the Absurd and of the Literature of the Absurd and compare them to Catch-22. I will analyze the novel's absurdist vision by looking at the absurdity of war, the absurdity of bureaucracy, absurdity of capitalism and at the famous catch-22. Further I will examine the failure of communication and the novel's structure. To come to a valid conclusion I will then analyze the significance of absurdity in Catch-22.

The Literature of the Absurd has its roots in the Theatre of the Absurd and the absurdist movement that emerged after World War II as a rebellion against traditional values and literature. Before the war it was commonly thought that man was a fairly rational creature who lives in an at least partly intelligible universe. It was believed that man was able to show heroism and dignity even in defeat. After the war then there was the tendency to view man as isolated and the universe as possessing no inherent truth, value or meaning. Jean Paul Sartre and Albert Camus, for example viewed the human being as an isolated existent who is cast into an alien universe, to conceive the universe as possessing no inherent truth, value or meaning, and to represent human life - in its fruitless search for purpose and meaning, as it moves in the nothingness whence it came toward the nothingness where it must end - as an existence which is both anguished and absurd. (Potts.W Stephen,1999)

At the night of 1955, Joseph Heller found himself contemplating of Louis-Ferdinand Celine's Journey to the End of the Night when, all out of sudden, the first line of what was to become Catch-22 came into his mind. That same year, Joseph Helle wrote, rewrote, and published "The Texan," the first chapter of the novel he called Catch-18 in New World Writing no. 7, an anthology dedicated to novels in progress. At the same time as Heller wrote the first chapter of what became the bestselling work of serious literature in American publishing history, Alfred A. Knopf published the first American edition of The Myth of Sisyphus, Albert Camus's deep analysis of the absurdity of the human condition. It is considered "the most broaden treatment of the philosophical Absurd," Camus's writings provides useful insight for anyone approaching the work of Joseph Heller, an author whose novels, according to Steven Potts, present "a vision of a bleak universe that, in Absurd, existentialist trend, lacks meaning or inherent values" (Potts W.Stephen ,1995) 
The individual tent to possess a number of "ideas or illusions that give them a reason for living" for Camus. (Potts W.Stephen; Antiheroic Antinovel; "From Here to Absurdity"1995) As long as the human being maintains a belief in such an illusion, he or she will remain satisfied, despite living what Martin Esslin reveals as "an existence that has become trite, mechanical, complacent".

The deceptive meaning of comfort a person feels towards his or her existence results from the undoubted recognition of some instructive principle leading human life into an easily comprehended and acquired model. The redemption felt towards the structure of his or her life stimulates an illusory sense of certainty that the authority determining the structure unmistakable. For several people, a moment arises when "the chain of daily gestures is broken" ( Lyotard,Jean-Francois,1993) and he or she must confront the distracting absurdity lurking behind his or her cosy life. According to Camus, the "absurd moment" takes place when the individual faces with the inhumanity of humankind: At certain moments of serenity, the mechanical aspect of their gestures, their meaningless pantomime makes fool everything that surrounds them. A man is talking on the telephone behind a glass partition; you cannot hear him, but you see his dumb show: you wonder why he is alive.

This discomfort in the face of man's own inhumanity, this incalculable disorder before the image of what we are, this "nausea," as a writer of today calls it, is also the absurd. (Camus Albert "The Myth of Sisyphus"1991)For a second we stop to understand it because for centuries we have realized only the images and designs that we had attributed to it earlier...the world avoids us because it becomes itself again. That stage scenery masked by habit becomes again what it is. It withdraws at a distance from us" (Camus Albert,1991). Martin Esslin calls it "a universe deprived of what was once its focus and its living purpose, a world deprived of a generally accepted integrating principle, which has become disjointed, purposeless-absurd" (Camus Albert ,1991) that Joseph Heller's fiction displays. The extreme fatigue Heller's meaningless universe imposes upon his protagonists crush the human spirit and leads to a definitive confrontation with mortality, the only certainty such an existence permits. As David M. Craig argues, Heller "never accepts death.

The endings of his novels virtually yell at about its inevitability, but death remains an opponent to be grappled with, even though it cannot be overcome" (Craig David M,1997). Although, as Mordecai Richler notes in his 1984 review of God Knows for the New York Times, "Heller's subject matter has varied from novel to novel," the novelist repeatedly returns to the individual's struggle to strain meaning from an existence untremblingly moving towards the inevitability of death. Reviewed as a whole, Heller's novels represent a half century's struggle to articulate a way for the individual to live a dignified and genuine existence in the face of the Absurd. In order to make a persuasive case for his worldview, Heller at the very begining bombards his reader with evidence testifying to the fake nature of accepted truths about the world, obliging the reader to encounter the Absurd as his protagonists discover the human condition. Heller's novels systematically discover the relativity behind such accepted structures as the military, the American Dream, Western religion, Western philosophy, and the historical record in order to reveal the dark secret at the root of human suffering: the insatiable human appetite for power, prestige, and profit.

Once the reader joins Heller's protagonists in recognizing the negative motives hiding behind the illusory guiding principles of human existence, he or she must, along with Heller's fictional heroes, find a way to respond to the unfeeling cosmos. Through the actions and words of Captain John Yossarian, Robert Slocum, Bruce Gold, and King David, Joseph Heller examines the possible lifestyles available to the individual upon confronting the absurdity of the human condition. Yossarian, Heller's most famous protagonist, embraces an attitude that, according to Jean Kennard, "is basically that of Jean Paul Sartre and the early Albert Camus" (Sartre, Jean-Paul,1984)

In both Catch-22 (1961) and Closing Time (1994), Yossarianis rebelled toward the Absurd through behavior analogous to the actions embraced by Camus's absurd man in a state of revolt. Rather than is given to the "hateful" seduction to join the establishment, Yossarian engages in an "unceasing struggle" against the freedom rejecting "truths" that are the byproduct of corporate, government, and military interests (Camus Albert,1991).Yossarian's "continual rejection" of and "conscious dissatisfaction" with the inhumanity of self-serving authorities represents the authentic existence Camus advances as the most honorable and satisfying lifestyle for the absurd man. In Good as Gold, Bruce Gold, a college English professor finds himself enticed with the prospect of becoming U.S. Secretary of State, a possibility which forces him to exist "between Washington and New York, Gentile and Jew, the nihilism and opportunism of politicsa nd the viciousness and strangled love of family life" (Heller, Joseph,1984).

In the obliteration between Gold's ethnically-oriented Brooklyn life and his desired position in an anti-Semitic government administration, Heller locates an interesting and solely American variation on the existential Absurd. Yossarian's rebellion contains the "total absence of hope" for a restoration of a unifying belief to justify his existence, the "continual rejection," and "conscious dissatisfaction" Camus identifies as central to the Absurd revolt. Indignant and terrified by his inevitable he experiences extreme angst in the face of the Absurd that emphasizes the necessity of 
acknowledging, accepting, and ultimately revolting against the human condition. At first glance, as Richler observes, Joseph Heller's seven novels seem very different from one another. Beginning with Catch-22, each of Heller's novels returns to the theme of Absurdity, approaching the existential dilemma of the modem man from a different angle to emphasize the ubiquity of the Absurd and to present an overwhelming argument in favor of adopting the authentic lifestyle embraced by the French existentialist Albert Camus, as articulated in The Myth of Sisyphus. Martin Esslin, in his introduction to The Theater of the Absurd, notes that the individual's initial confrontation with the Absurd begins with a "sense that the certitudes and unshakable basic assumptions of former ages have been swept away, that they have been tested and found wanting, that they have been discredited as cheap and somewhat childish illusions" (Esslin Martin,1961).

In order to bring his reader into an appropriate state of mind in which to consider the options available to the Absurd individual, Joseph Heller uses novels such as Picture This, God Knows, and Catch-22 to undermine and "sweep away" the basic assumptions and assures governing human life. Heller's most blatant assault on humanity's faith in socially-constructed certitudes, Picture This, uses actual historical documents to unmask humanity's faith in Western art, philosophy, and the historical record itself. So, in one short passage, Joseph Heller's bitterly meticuluos narrator sets the tone for the entire novel. Taking just one of the many "fictions that have come down to us as 'fact,"' the narrator reveals, with the "gloomy wit and not unexpected cynicism" of a Heller protagonist, the spurious nature of artistic authority. By revealing the false "images and designs" with which the reader may have been deceived into undoubtly accepting the authenticity, the narrator makes it possible for the reader to perceive "the denseness and strangeness of the world that is the absurd"(Camus Albert,1991)

Before exploring Heller's treatment of the malignant motives lurking behind the illusory truths with which humanity seeks to obscure the absurd nature of the universe, however, a brief examination of Heller's earlier attempts at debunking faith in various authorities proves enlightening. He divests the world of another revered falsehood, Heller compounds the considerable doubt inspired by works such as Picture This and urges the reader to view the world as fundamentally absurd.One final example of Joseph Heller's use of fiction to weaken the reader's faith in institutional authority can be located in Catch-22"s treatment of Great Depression era agricultural subsidizations. By briefly recalling the benefits given to Major Major's father by the United States government, Heller draws the reader's attention to the inherent fallibility of such venerated institutions. As Steven Potts observes, "Major Major's father is portrayed as a salt-ofthe-earth American, a Calvinist farmer who preaches traditional American values" (Potts W.Stephen,1995).

In other words, Heller clearly identifies Mr. Major as the ideal representative of the demographic to which such socialistic benefits were extended. However as Heller notes: His specialty was alfalfa and he made a good thing out of not growing any. The government paid him well for every bushel of alfalfa he did not grow. The more alfalfa he did not grow, the more money the government gave him, and he spent every penny he didn't earn on new land to increase the amount of alfalfa he did not produce. Major Major's father worked without rest at not growing alfalfa. On long winter evenings he remained indoors and did not mend harness, and he sprang out of bed at the crack of noon every day just to make certain that the chores would not be done. He invested in land wisely and soon was not growing more alfalfa than any other man in the country and he made much money.

Although the account of Mr. Major's deceitful agricultural practices initially appears to be more of a criticism of greed than an indictment of governmental fallibility, a closer consideration of the passage reveals Heller's invitation for the reader to question his or her faith in competent government. By weakening the reader's faith in so many institutions, Joseph Heller forces the individual to realize, in Jean Kennard's words, that: "when everything is questionable, it is a small step to questioning one's own identity" and realizing that "the authoritative values which determine the rules of behavior are man-made," (Kennrad, Jean-1971) not the certainties he or she had presumed they were. This realization uncovers the disturbing possibility that the "world has no meaning but is simply there". For Camus, "the momen absurdity is recognized, it becomes a passion, the most harrowing of all" (Camus Albert,1991) and the individual seeks an understanding of the world hitherto unavailable. He or she, having achieved awareness, senses the utter pointlessness of human suffering and indignantly recognizes the selfish interests motivating this misery. Once the individual swallows the bitter pill of Absurd recognition, he or she faces what Camus calls the "constant confrontation between man and his own obscurity" and a choice between an existentially authentic life of revolt or an inauthentic life of self-deceit and spiritual death. Joseph Heller uses this scene to depict a decidedly bleak interpretation of the motives driving mankind before unreservedly promoting a life lived with "the certainty of a crushing fate, without the recognition that ought to accompany it" (Heller,Joseph ;2000).

Perhaps nowhere in Joseph Heller's fiction is the inhumanity of mankind presented in such harrowing detail and at such length as in the thirty-ninth chapter of Catch-22, "The Eternal City." Although a sizable amount of critical attention 
has been paid to this famous passage, the most extensive and insightful examination to date remains Minna Doskow's essay, "The Night Journey in 'Catch-22,"' first published in 1967. In Doskow's opinion, Rome is "a city of universal destruction," a microcosm of the modem world (Doskow, Mina;1967).

Yossarian begins his journey through the Italian capital in an effort to locate and help the younger sister of Nately's Whore who had been chased "away with the rest of the broads" by military policemen when dismantling a makeshift brothel frequented by enlisted men and officers on leave. Immediately, Yossarian questions what possible motivations the authorities might have had for evacuating the women and thrusting a defenseless twelve-year-old girl "right out into the street" (Heller, Joseph ;2000)

Having enlisted the assistance of Milo Minderbinder, Yossarian sets out to locate the missing child. Milo initially expresses glowing approval of Yossarian's humanitarian mission but after learning that "the profit in illegal tobacco is very high," Milo abandons the search. When Yossarian questions him, Milo assumes "a look of epileptic lust" and starts "towards the door as though in a spell," repeatedly muttering "Illegal tobacco, illegal tobacco". Donald Monk interprets Milo's behavior as "capitalist free enterprise run amok" and cites it as evidence of the "kind of profit-motive which permits the moral viciousness" plaguing modem society. Having lost Milo to the lure of fiscal gain, Yossarian seeks assistance from the police commissioner, but the official only desires to resume "fiddling with a stout woman with warts and two chins" and threatens to arrest Yossarian if he does not leave the station. Thus, greed and lust prevents a military official and a policeman from attempting to save a girl in danger. As Yossarian continues through "the streets encountering sickness hunger, poverty, sadistic cruelty and coercion and viewing an entire gallery of mutilated bodies and warped souls,"(Doskow, Mina ;1967) the reader cannot help wondering just how much of the degradation and pain he encounters is the result of similar motives. Elsewhere in Catch-22, the reader encounters Colonel Cathcart, "a simon-pure opportunist," as Granville Hicks writes, "who will stop at nothing to get promoted, who is constantly courting the favor of his superiors, who does not care how many men are killed if he can get a little favorable publicity" ( Hicks Granville;1967). Cathcart longs "to be a general so desperately he was willing to try anything," including a warped attempt to impress the editors of The Saturday Evening Post by forcing his squadron to perform staggering numbers of dangerous bombing missions. Although many of the best men in his command die while flying superfluous bombing missions, Cathcart "never hesitates to volunteer his men for any target available". Made indifferent by his monomaniacal desire for fame, Cathcart does not care that his men have already flown more missions than required of them and decides that "no target was too dangerous for his group to attack". Later in the novel, Cathcart orders his men to create a roadblock for the Germans by "bombing a tiny undefended village, reducing the whole community to rubble". Although "the mission is entirely unnecessary" and its sole purpose "is to delay German reinforcements at a time when the U.S. is not even planning an offensive," Cathcart forces his men to fly in hopes of snapping a few impressive aerial photographs. When the men of the squadron express horror at the prospect of killing peaceful people who will "pour out into the streets to wave when they see the planes coming, all the children and dogs and old people," Colonel Kom only emphasizes Cathcart's desire for "a good clean aerial photograph he won't be ashamed to send through channels" in hopes of impressing General Peckem with a tight bomb pattern. Disturbingly, a "bomb pattern" is nothing more than an empty neologism coined by the General. As Peckem explains to Schiesskopf: A bomb pattern is a term I dreamed up just several weeks ago. It means nothing but you'll be surprised at how rapidly it's caught on. Why l've got all sorts of people convinced I think it's important for the bombs to explode close together and make a neat aerial photograph. In Catch-22, military authorities such as those represented by Cathcart, Kom, and Peckem do not care about the value of human life. For men such as Cathcart, men are expendable tools which can be used to build a statistical profile that may impress the editors of newspapers. He dehumanizes the innocent people in the tiny mountain hamlet into barely visible components of a photograph he hopes will earn him the esteem of other military officials as well as the aforementioned newspaper editors. Clearly, in the world of Catch-22, the powerful will pursue their passions at the expense of anyone standing in their way. This motif, however, is not limited to the pages of Heller's most famous novel, but runs through the entirety of his work.

In Something Happened, as Thomas Le Clair observes, "corporate value poisons private life"(Heller Joseph "Heller, Joseph;2000) since the policies of the company employing Slocum affect the private lives of its employees. Thus, for Slocum, family life is important only as a way to improve his career. The appearance of a successful marriage, for instance, is pivotal in vocational security: Unmarried men are not wanted in the Sales Department, not even widowers, for the company has learned from experience that it is difficult and dangerous for unmarried salesmen to mix socially with prominent executives and their wives or participate with them in responsible civic affairs ... If a salesman's wife dies and he is not ready to remarry, he is usually moved into an administrative position after several months of mourning. Bachelors are never hired for the sales force, and salesmen who get divorced, or whose wives die, know they had better 
remarry or begin looking ahead to a different job. Since family life is inextricably linked to corporate success and because Bob Slocum's business aspirations dominate his existence, he refuses to condone dissent within his household. For instance, when his wife and teenage daughter begin discussing the girl's desire to leave home, Slocum forbids further discussion by adopting a "potent and articulate" counterargument Immediately upon recognizing his "victory," Slocum "wishes that Green or someone else I yearn to impress in the company, like Jane or Horace White ... were in a position to witness me so fluent and dominating". Since strong debating skills are valued at work, Slocum relishes his ability to exercise them at home, quashing in the process any undesirable elements. The result of such behavior, Slocum observes, is that his "wife is unhappy," his "children are unhappy," and his "little boy is having a difficult time".

Sadly, Slocum realizes the extent to which his corporate mentality harms his family and decides, despite its malignant effect, "I want the money. I want the prestige" (Heller,Joseph;2000).The full force of the self-serving attitude inspiring so much misery emerges in Slocum's epigrammatic self assessment, "I am a shit. But at least I am a successful one". Elsewhere in Heller's work, human suffering emerges as the omnipresent byproduct of humankind's selfish desire for power. In Good as Gold, "the American economic system was barbarous, resulting naturally in barbarianism and entrenched imbecility on all levels of culture. Technology and finance mass-produced poverty at increasing speed. In God Knows, David recalls starting wars because something in man requires an enemy, something in mankind demands a hostile balance of power. In Closing Time, wealthy people squander money that could be used to help the poor because "even in a recession, the country was awash in money. Even amid poverty, there was room for much waste" (Heller Joseph;1994), while the government seeks "everlasting fame" by developing "the ultimate weapon that could lead to the end of the world" and causing widespread paranoia in the process. Clearly, Heller seeks to convince his readers of a general selfishness lurking behind many of mankind's guiding mentalities, but he also advances the belief that those in power camouflage their malevolence and greed in order to deceive people who will object to the indifference the powerful hold towards those they oppress. Picture This effectively demonstrates the ubiquitous presence of these malignant motivations by examining three distinct periods of human history: the Athenian Golden Age, the seventeenth century Dutch Golden Age, and the Cold War of the late twentieth century. The narrator matter-of-factly proceeds through his history lesson, detachedly covering some of the most lamentable events in Athenian and Dutch history in terms eerily appropriate to situations occurring in the latter half of the twentieth $\mathrm{c}$.

In conclusion, the individual, upon processing the magnitude of the absurd discovery must either revolt against the cruel and unfeeling cosmos or retreat into an inauthentic acceptance of the brutally arbitrary conditions of human suffering. Recognizing the essential pointlessness of life, the reader indignantly senses that the suffering he or she experiences results from the self-serving actions of other people. By "inviting the reader to make connections" between past epochs and his or her own society, the narrator enables his audience to realize that a great many presumptions about the natural order of the world are nothing more than convenient facades for the greedy interests of those people holding power. Having already forced the reader to consider the terrifying absurdity inherent to the human condition, Heller angers the reader by revealing the stupefying prevalence of greed and indifference in the world.

\section{References}

Craig, David M.Tilting at Mortality: Narrative Strategies in Joseph Heller's Fiction, Detroit Wayne State UP; 1997.

Doskow, Mina. "The Night Journey in Catch-22."1967

Martin, Esslin. "Theatre of Absurd". Garden City:Doubleday,1961

Heller, Joseph. "A Portrait of an old man"New York:Simon and Schuster, 2000

Catch-22.New York: Scribner, 1996

Something Happened. New York: Scribner, 1997

Hicks, Granville. "Medals for Madness".Rev. of Catch-22.by Joseph Heller.Nagel, Critical Essays on Catch-22

Kennard, Jean "Joseph Heller: At War with Absurdity" 1971

Lyotard, Jean-Francois."Excperts from Postmodern Condititon” 1993

Monk, Donald "An Experiment in Therapy: A study of Catch-22, 1970

Richter, David,H.Fable's End: Completeness and Closure in Rhetorical Fiction" 1974 